\title{
JUURNAL.RU
}

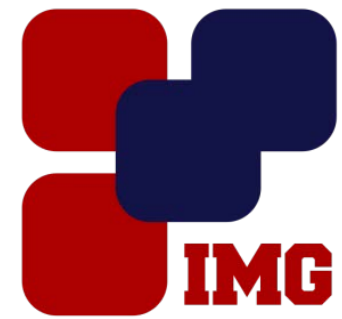

Ivanoy
Management
Group

Ян Цзихун

Северо-Восточный федеральный университет имени М. К. Аммосова, Филологический

факультет

Якутск, Россия

doi: 10.18411/lj-28-02-2017-4-09

idsp 000001:lj-28-02-2017-4-09

\section{Проблемы преподавания русского языка в вузах Китая}

\section{Аннотация}

В настоящее время взаимоотношение Китая с Россией характеризуется тесными связями. При дальнейшем экономическом и культурном обмене и сотрудничестве между двумя странами, которые будут остро нуждаются в большом количестве работников, владеющих русским языком. Сегодня во многих вузах Китая открыта специальность русского языка. В данной статье обсуждается нынешнее состояние преподавания русского языка, анализируются проблемы преподавания русского языка в вузах Китая.

Ключевые слова: русский язык в Китае, преподавание русского языка в вузах Китая, ситуация и проблемы обучения русскому языку.

По данным Министерства образования КНР, теперь русский язык в Китае как основная специальность изучается в 137 вузах. В настоящее время в стране 50 вузов набирают студентов в магистратуру, 10 вузов - докторантуру, 6 вузов проводят работу кандидатов для ведения пост-доктора. В китайских вузах русский язык преподают больше 1000 специалистов, в том числе около 200 профессоров и больше 400 доцентов [1]. Хотя в последние годы при обучении русскому языку мы получаем много успехов, между тем в этом процессе существуют несколько проблем.

При процессе преподавания русского языка в вузах КНР имеются многие проблемы.

\section{1.С точки зрения условий обучения.}

С одной стороны, это вопрос о преподавателях, кто к развитию образования играет важную роль. В данном случае из-за некоторых вузах обращают меньше внимания на образование русского языка, так как не хватает специалистов, преподавателей русского языка. Способных преподавателей по русскому языку не хватает, и степень многих преподавателей на факультете является относительно 
слабым, который непосредственно влияет на качество преподавания русского языка. С другой стороны, методы и средства на многих аудиториях простые и старые (доска, мел), с которыми трудно достичь педагогической эффективности. На занятиях отсутствие языковой среды, бывает такая ситуация--преподаватель объясняет, а студенты слушают и мало говорят по-русски, мало языковой практики для изучающих, для них практических шансов мало, потом приводит к плохому учебному результату.

\section{2.С точки зрения студентов.}

Для многих студентов набор специализированных курсов они чувствуют себя апатию, они не заинтересованы в изучении профессиональных курсов, у них отсутствие интереса к учебе, что прямо снижает энтузиазм студентов. Кроме того, студентам, изучающие русского языка, трудно искать подходящую работу и поступать в магистратуру., из-за этого некоторые студенты отказаться от изучения русского языка.

\section{3.С точки зрения вузов.}

Сегодня многие вузы дают недостаточно внимания вопросам образования русского языка, они чувствуют, что при экономическом и социальном окружении глобализации общество нуждается в развитии навыков английского языка, и изучение русского языка просто не важнее, чем изучение английского языка. В многих вузах даже отменили преподавание русского языка [2].

Чтобы решать проблемы преподавания русского языка в вузах Китая, можем принять соответствующие меры.

Во-первых, акцент на преподавательский комплекс. Вначале надо улучшить навыки преподавателей, для них регулярно открыты лекции о новых методах и приёмах обучения, а затем преподаватели общаются друг с другом, обмениваются опытом, чтобы быстро улучшить степень преподавания. Вместе с этим нужно приглашать хороших русских преподавателей, которые могут приносить хороший горизонт обучения. И наконец, необходимо развивать чувство инноваций в преподавателях русского языка., используя современное мультимедийное учебное оборудование в педагогике [3]. Сторона вузах должна правильно понимать цель развития образования русского языка. Акцент на подготовку к изучающим, чтобы предоставить студентам хорошую окружающую среду изучения, приглашают изучающихся на конференции, лекции, семинары и т.д. Во-вторых, как преподаватель русского языка, надо не прерывно развивать интерес учащихся к обучению, чтобы мобилизовать студентов энтузиазм и мотивацию к обучению, это будет достигнуто очень хороший эффект преподавания. Поэтому преподавателя должны использовать различные средства, найти способы, чтобы стимулировать студентов интерес к учёбе на аудитории. На занятиях преподавателя могут добавить некоторые новые содержания, которые интересуют студентов, так что это может привлечь их внимание на изучение. Необходимо проводить интерактивное обучение, преподаватель и студенты общаются друг с другом по-русски. Кроме того, преподаватели должны направлять студентов, 
чтобы правильно узнать профессиональные перспективы трудоустройства, чтобы укрепить их доверие к обучению.

Чтобы удовлетворить потребности социально-экономического развития между Россией и Китаем, улучшение качества преподавания русского языка становится важной задачей.

\section{Литература}

1. Лю Сумэй, Обучение русскому языку в вузах Китая: состояние и перспективы // Русский язык за рубежом.2014. No4.C120-123.

2. Чжан Вэй, Е.В.Лазарева, Обучение русскому языку в Китае: опыт факультета русского языка Цилинского института иностранных языков Хуацяо // Русский язык за рубежом.2012. No6.C108-114.

3. Ван Дянься, Состояние и проблемы при обучении русскому языку в Вузах Китая. //Образование "Шэньчжоу". 2013.C113. 